\title{
PHYSIOLOGICAL RESPONSES OF COWPEA UNDER WATER STRESS AND REWATERING IN NO-TILLAGE AND CONVENTIONAL TILLAGE SYSTEMS ${ }^{1}$
}

\author{
RÔMULO MAGNO OLIVEIRA DE FREITAS ${ }^{2 *}$, JEFERSON LUIZ DALLABONA DOMBROSKI ${ }^{3}$, FRANCISCO \\ CLÁUDIO LOPES DE FREITAS ${ }^{4}$, NARJARA WALESSA NOGUEIRA ${ }^{3}$, JOSÉ RIVANILDO DE SOUZA PINTO ${ }^{3}$
}

\begin{abstract}
The goal of this work was to evaluate the physiological responses of cowpea under water stress and rehydration in conventional and no-tillage systems. We evaluated two crop systems (conventional and no tillage) and three water conditions (no stress, moderate stress and severe stress). The following were determined: leaf area, total dry matter, photosynthetic rate, stomatal conductance, transpiration rate, internal $\mathrm{CO}_{2}$ concentration and leaf water potential. Water stress affected all variables evaluated, with the exception of leaf water potential. Cowpea recovered with respect to all variables after rehydration at both stress levels. Stomatal closure is an important drought tolerance mechanism, and cowpea can be considered a conservative species (i.e., one that prioritizes water status maintenance rather than photosynthetic rate). Planting systems did not affect photosynthetic rate. The tillage system promoted greater accumulation of biomass and higher leaf area.
\end{abstract}

Keywords: Leaf area. Photosynthesis. Stomatal conductance. Vigna unguiculata. Water potential.

\section{RESPOSTAS FISIOLÓGICAS DE FEIJÃO-CAUPI SOB ESTRESSE HÍDRICO E REIDRATAÇÃO EM PLANTIO DIRETO E CONVENCIONAL}

RESUMO - O objetivo do trabalho foi avaliar as respostas fisiológicas em feijão-caupi sob efeito de estresse hídrico e reidratação nos sistemas de plantio direto (PD) e convencional (PC). Foram avaliados dois sistemas de plantio (direto e convencional) e três condições hídricas (sem estresse, estresse moderado e estresse severo). Foram determinados: área foliar, matéria seca total, fotossíntese, condutância estomática, transpiração, concentração interna de $\mathrm{CO}_{2}$ e potencial hídrico foliar. $\mathrm{O}$ estresse hídrico afetou todas as variáveis avaliadas, com exceção do potencial hídrico foliar. Houve recuperação de todas as variáveis após reidratação em ambos níveis de estresse. O fechamento estomático é um importante mecanismo de tolerância à seca, sendo que o feijão-caupi pode ser considerado uma espécie conservadora, i.e. que prioriza a manutenção do status hídrico em detrimento da produção fotossintética. Os sistemas de plantio não afetaram as taxas fotossintéticas. O sistema de plantio direto promove maior acúmulo de biomassa e maior área foliar.

Palavras-chave: Área foliar. Fotossíntese. Condutância estomática. Vigna unguiculata. Potencial hídrico.

\footnotetext{
*Corresponding author

${ }^{1}$ Received for publication in $07 / 05 / 2015$; accepted in 10/19/2016.

Paper extracted from the doctoral thesis of the first author.

${ }^{2}$ Instituto Federal de Educação, Ciência e Tecnologia Baiano, Valença, BA, Brazil; romulomagno_23@hotmail.com.

${ }^{3}$ Agrarian Sciences Center, Universidade Federal Rural do Semi-Árido, Mossoró, RN, Brazil; jerferson@ufersa.edu.br, narjarawalessa@yahoo.com.br, rivanildo.ufersa@gmail.com.

${ }^{4}$ Department of crop science, Universidade Federal de Viçosa, Viçosa, MG, Brazil; fclaudiof@yahoo.com.br.
} 


\section{INTRODUCTION}

Water stress is a situation common to many crops and constitutes one of the major factors that affects agricultural production, influencing virtually all aspects related to plant development (DAMATTA, 2007). The extent of damage caused by water stress varies according to duration, intensity, frequency, time of occurrence and genotype. The frequency and intensity of water deficit are the most important factors regarding restrictions to global agricultural production (SANTOS; CARLESSO, 1998).

The strategies of plants to cope with water stress can be divided into three types: drought escape, water conservation and drought tolerance (SALEHI-LISAR; BAKHSHAYESHAN-AGDAM, 2016). Escape is the strategy used by plants with a short lifecycle, in which they complete their lifecycle during the rainy season of the year, avoiding the dry season. Water conservation includes strategies that favor the maintenance of the water status of the plant at the expense of photosynthetic production. Drought tolerance corresponds to mechanisms that involve trying to keep the stomata open for as long as possible, even at the expense of reduced water potential or dehydration of tissues.

Thus, subsistence farming in semi-arid regions mainly uses the escape strategy. However, due to the rainfall irregularity of such regions, experiencing long periods without rain during the crop cycle, known as "Indian summers", is common. In this case, survival of plants and crop yield will depend on various strategies that could be classified as water conservation or drought tolerance.

Cowpea (Vigna unguiculata (L.) Walp.) is a native crop of western Africa and one of the most important legume food crops grown in semi-arid tropics; Asia; Africa; southeastern Europe; and Central and South America, specifically for its development and yield capacity in areas where other crops do not grow well due to high temperatures and erratic rainfall (AKIBODE; MAREDIA, 2011). Cowpea is one of the main sources of protein for families farming in these regions. In northeastern Brazil, cowpea also has a very strong cultural importance (FREIRE FILHO, 2011). In terms of planted area, cowpea is the second-most important legume food crop in the world (AKIBODE; MAREDIA, 2011).

The cowpea crop has a good ability to withstand Indian summers, especially when they occur during the vegetative phase; the plants show capacity to recover their growth very effectively with the return of the rains (HALL, 2012). The number and duration of Indian summers, coupled with high temperatures, reduce cowpea yield, especially when
Indian summers occur during the stages of flowering and grain filling (MENDES et al., 2007).

The no-tillage system is considered a promising technique to reduce the effects of Indian summers when compared to the conventional tillage systems (FREITAS et al., 2014) by using crop residue for soil cover in order to keep in moisture (FREITAS et al., 2013). Mulch acts as an insulating agent, preventing sharp fluctuations in soil temperature and contributing to less evaporation of stored water and to better use of soil water by plants (MAROUELLI et al., 2006; BIZARI et al., 2009; OBALUM; OBI, 2010).

In addition to knowing the strategies of physiological adaptations of crops, it is important to know the interaction of these factors with forms of management that allow the minimization of the water stress effect. Given the above, the objective of this study was to evaluate the physiological responses of cowpea under water stress and rewatering in no-tillage and conventional tillage systems.

\section{MATERIAL AND METHODS}

The experiment was conducted in the garden of the Department of Plant Sciences at the Federal Rural University of the Semi-Arid (UFERSA), Mossoró-RN, between September and December 2011. The city of Mossoró-RN is located in northeastern Brazil at the following geographic coordinates: $5^{\circ} 11^{\prime}$ south latitude, $37^{\circ} 20^{\prime}$ west longitude, at an altitude of $18 \mathrm{~m}$. The soil of the region is classified as a eutrophic Red-Yellow Argisol (SANTOS et al, 2006).

During the crop cycle, a maximum temperature of $33.5{ }^{\circ} \mathrm{C}$, average of $27.9{ }^{\circ} \mathrm{C}$ and minimum of $23.6{ }^{\circ} \mathrm{C}$ (Figure 1A) were observed. Regarding air relative humidity, a maximum of $79.1 \%$, average of $60.9 \%$ and minimum of $35.5 \%$ (Figure 1B) were observed. During the research, only one rain event was observed, at 31 days after sowing (DAS), of $5 \mathrm{~mm}$.

Two planting systems were used in the research: no tillage and conventional. In the area of the no-tillage system, to obtain straw, planting of Brachiaria stapt. cv. Marandue was carried out during the rainy season, and 30 days before the setup of the experiment, desiccation was performed with $1.90 \mathrm{~kg} \mathrm{ha}^{-1}$ of glyphosate herbicide. In the area intended for conventional tillage, tillage was made with one plowing and two disking events. These areas were cultivated in the no-tillage and conventional tillage systems during the 4 years prior to the setup of the experiment. 

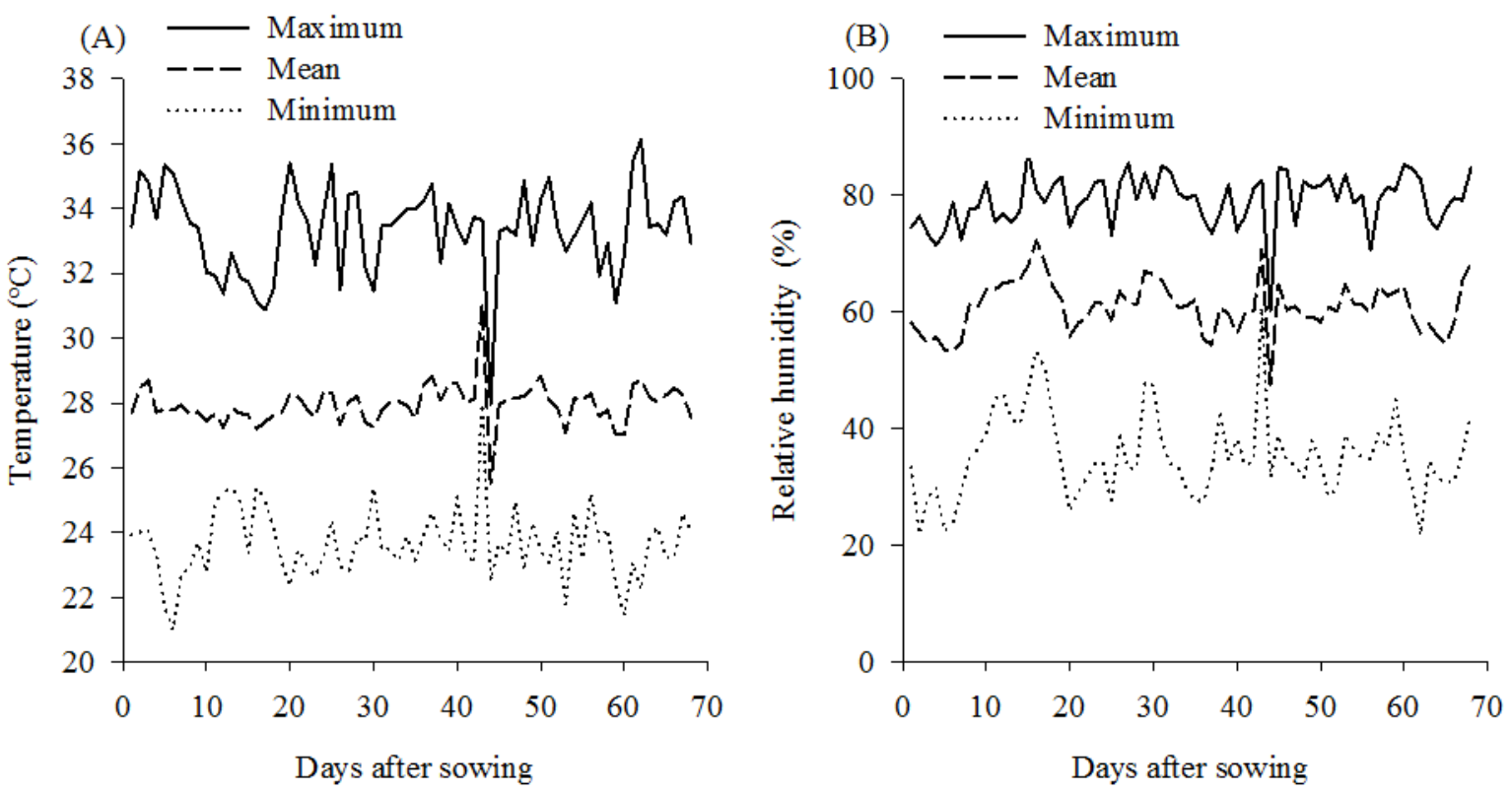

Figure 1. Temperature (A) and air relative humidity (B) during the experiment.

For each planting system, a soil sample to a depth of up to $20 \mathrm{~cm}$ was taken from the experiment area for chemical analysis, with the goal of determining fertility. The following chemical characterization of the soil was recorded: $\mathrm{pH}$ (water) of 6.1 and 6.2 ; organic matter of 10.1 and $12.9 \mathrm{~g} \mathrm{~kg}^{-1}$; phosphorus (P) of 220.4 and $127 \mathrm{mg} \mathrm{dm}^{-3}$; potassium $\left(\mathrm{K}^{+}\right)$of 157.3 and $160.3 \mathrm{mg} \mathrm{dm}{ }^{-3}$; calcium $\left(\mathrm{Ca}^{2+}\right)$ of 3.65 and $3.40 \mathrm{cmolc} \mathrm{dm}^{-3}$; magnesium $\left(\mathrm{Mg}^{2+}\right)$ of 1.00 and $1.05 \mathrm{cmolc} \mathrm{dm}^{-3}$; and aluminum $\left(\mathrm{Al}^{3+}\right)$ of 0.15 and $0.20 \mathrm{cmolc} \mathrm{dm}^{-3}$ in the conventional and no-tillage systems, respectively.

After soil preparation and demarcation of the experiment, a drip irrigation system was installed in the planting row, with emitters of $1.7 \mathrm{~L} \mathrm{~h}^{-1}$ spaced $0.3 \mathrm{~m}$ apart. In order to avoid differences in the water supply for treatments, daily readings of tensiometers randomly installed were performed, with two tensiometers per treatment at a $20-\mathrm{cm}$ depth. To control irrigation, a record was made in each subplot. Each plot consisted of four rows $5 \mathrm{~m}$ in length, spaced $0.5 \mathrm{~m}$ apart, with the two central rows considered the useful area, discarding $0.5 \mathrm{~m}$ on each end. To ensure isolation, each subplot was spaced $1 \mathrm{~m}$ apart.

The cowpea cultivar used was BRS Guariba, of semi-erect growth, intended for dry grain production. Sowing and fertilization were performed with the use of a rattle, set to 2-4 seeds per hole, and with $250 \mathrm{~kg} \mathrm{ha}^{-1}$ NPK in the formulation 6-24-12. The adopted spacing was $0.3 \mathrm{~m}$ between holes. After emergence, thinning was performed, leaving two plants per hole.

In the conventional tillage system, weed control was carried out manually with the use of a hoe, with hoeing being performed at 15 and 30 DAS. In the no-tillage system, weeds were mowed at 25
DAS, in a localized form.

At the flowering stage, at $34 \mathrm{DAS}$, during which $70 \%$ of plants had at least one flower, the imposition of different water conditions began. Plants that did not undergo water stress were irrigated with water at a 2-day irrigation frequency throughout the experiment, maintaining the soil close to $70 \%$ of field capacity; those that underwent water stress had their irrigation suspended. Plants were monitored daily during the suspension of irrigation, being irrigated again (rewatered) when the $\mathrm{CO}_{2}$ assimilation rate at 9:00 a.m. corresponded to about $40 \%$ of the photosynthesis of plants considered as a reference (irrigated) for moderate stress and close to zero for severe stress, which occurred at 44 and 52 DAS, respectively. After the rewatering, plants continued to be evaluated until the $\mathrm{CO}_{2}$ assimilation rates at 9:00 a.m., for severe stress, were similar between treatments.

To evaluate growth, sampling was carried out every 7 days (between 15 and 64 DAS). Four plants were used per treatment, determining the variables total dry matter (TDM), by weighing the dry material in an oven at $65{ }^{\circ} \mathrm{C}$ to constant weight, and leaf area $\left(\mathrm{LA} ; \mathrm{cm}^{2}\right)$, determined by the fixed disk method (SOUZA et al., 2012).

The following also were evaluated: photosynthesis $\left(A ; \mu\right.$ mol $\left.\quad \mathrm{CO}_{2} \quad \mathrm{~m}^{-2}\right)$, stomatal conductance $\left(g s ; \mu \mathrm{mol} \mathrm{H}_{2} \mathrm{O} \mathrm{m}^{-2} \mathrm{~s}^{-1}\right)$, transpiration $(E$; mmol $\mathrm{H}_{2} \mathrm{O} \mathrm{m} \mathrm{m}^{-2} \mathrm{~s}^{-1}$ ) and internal $\mathrm{CO}_{2}$ concentration $\left(\mathrm{C} i ; \mu \mathrm{mol} \mathrm{CO}_{2} \mathrm{~m}^{-2}\right.$ ), with the aid of an LI-6400 photosynthesis meter ( Li-6400XT IRGA, LI-COR. Lincoln, NE, USA). $\mathrm{CO}_{2}$ levels were set at $400 \mu \mathrm{mol} \mathrm{m} \mathrm{m}^{-2} \mathrm{~s}^{-1}$ and the light intensity at $1500 \mu \mathrm{mol}$ photons $\mathrm{m}^{-2} \mathrm{~s}^{-1}$. The measurements were performed on young, newly expanded, undamaged and well-lit leaves (when the light intensity was greater than $1000 \mu \mathrm{mol}$ photons $\mathrm{m}^{-2} \mathrm{~s}^{-1}$ ). 
The water potential $\left(\Psi_{\mathrm{w}} ; \mathrm{MPa}\right)$ of the plants was determined at pre-dawn and noon with the aid of a pressure pump (Schollander pump). Fully expanded, undamaged and well-lit leaves were used.

The experiment was conducted in a randomized block design, with a subsampling and sub-subsampling scheme, with four replications. In the plots, the two planting systems (conventional and no tillage) were evaluated, in the subplots, three water conditions (without stress, moderate stress and severe stress) and in the sub-subsampling the evaluation periods. Data were submitted to analysis of variance and means were compared by the Student-Newman-Keuls test at 5\% probability for each system and evaluation period. Statistical analyses were performed by the ASSISTAT program version 7.6 beta (SILVA; AZEVEDO, 2002).

\section{RESULTS AND DISCUSSION}

The growth of cowpea was influenced by water restriction and the planting systems for the variables LA and TDM (Table 1). From 36 DAS, 2 days after the start of treatments, there was a stop in the increase of LA and TDM for the two planting systems in the treatments where there was suspension of irrigation (Figure 2). After the resumption of irrigation, there was a recovery of the increase in TDM, which was not observed for LA.

Table 1. Summary of the analysis of variance for the variables leaf area (LA); total dry matter (TDM); photosynthesis $(A)$; stomatal conductance $(g s)$; transpiration $(E)$; internal $\mathrm{CO}_{2}$ concentration $(C i)$; and leaf water potential at pre-dawn $\left(\Psi_{\mathrm{w} 3)}\right.$ and noon $\left(\Psi_{\mathrm{w} 12}\right)$ in cowpea.

\begin{tabular}{ccccccccc}
\hline \multirow{2}{*}{ Variety factor } & \multicolumn{7}{c}{ Values of F } \\
\cline { 2 - 8 } & LA & TDM & $A$ & $g s$ & $E$ & $C i$ & $\Psi_{\mathrm{w} 3}$ & $\Psi_{\mathrm{w} 12}$ \\
\hline Systems (A) & $25.82^{*}$ & $37.759^{* *}$ & $0.061^{\mathrm{ns}}$ & $0.037^{\mathrm{ns}}$ & $24.08^{* *}$ & $0.308^{\mathrm{ns}}$ & $1.614^{\mathrm{ns}}$ & $0.016^{\mathrm{ns}}$ \\
Stress (B) & $350.1^{* *}$ & $625.19^{* *}$ & $149.4^{* *}$ & $96.61^{* *}$ & $46.76^{* *}$ & $59.39^{* *}$ & $0.006^{*}$ & $0.989^{\text {ns }}$ \\
AxB & $16.43^{* *}$ & $10.93^{* *}$ & $2.744^{\text {ns }}$ & $0.364^{\text {ns }}$ & $0.403^{\text {ns }}$ & $1.229^{\text {ns }}$ & $2.594^{\text {ns }}$ & $0.259^{\text {ns }}$ \\
Evaluation (C) & $16.23^{* *}$ & $31.98^{* *}$ & $54.07^{* *}$ & $21.05^{* *}$ & $15.67^{* *}$ & $22.94^{* *}$ & $10.63^{* *}$ & $7.229^{* *}$ \\
AxC & $2.009^{\text {ns }}$ & $1.363^{\text {ns }}$ & $2.157^{*}$ & $4.446^{* *}$ & $3.501^{* *}$ & $1.358^{\text {ns }}$ & $0.935^{\text {ns }}$ & $1.563^{\text {ns }}$ \\
BxC & $22.29^{* *}$ & $25.98^{* *}$ & $22.11^{* *}$ & $14.60^{* *}$ & $17.61^{* *}$ & $11.18^{* *}$ & $1.116^{\text {ns }}$ & $0.843^{\text {ns }}$ \\
AxBxC & $2.358^{* *}$ & $0.977^{\text {ns }}$ & $2.185^{* *}$ & $3.576^{* *}$ & $1.013^{\text {ns }}$ & $0.637^{\text {ns }}$ & $1.154^{\text {ns }}$ & $0.914^{\text {ns }}$ \\
\hline
\end{tabular}

* Significant at $5 \%$ probability.

** Significant at $1 \%$ probability.

n.s. Not significant.

The almost immediate stoppage of plant growth after the suspension of irrigation is evidence of the strategy of the species to conserve water, since stomatal closure prevents photosynthesis and, therefore, plant growth. With the resumption of irrigation, the plants were in full reproductive stage, dedicating their resources to the formation of reproductive structures (flowers, flower stalks and pods). During this occasion, there is a stoppage of the actions toward photoassimilates to form new leaves (source), and the reproductive structures become the main sink (FREITAS et al., 2014). Thus, at this time, there is an increased percentage of dry weight of fruits in relation to other organs (FONTES; DIAS; SILVA, 2005; SILVA et al., 2010; LOPES et al., 2011; FREITAS et al., 2014).

The no-tillage system in the control treatment provided higher accumulation of LA and TDM than the conventional tillage system (Figure 2). A significant increase of LA and TDM in the no-tillage system between 29 and 36 days was observed, compared to those of conventional tillage. Even though there is a reduction in the growth rate of LA after that period in both planting systems, which is associated with the transition to the reproductive stage (FREITAS et al., 2014), it is clear that the TDM, both in the conventional and no-tillage system, maintained the growth trend at 57 days. Since there was no change in the photosynthetic rates among the planting systems (Table 1), it is understood that the increase in TDM is due to higher LA accumulation in the no-tillage system. In turn, the largest LA accumulation in the no-tillage system can be explained by specific features of no tillage, with greater water retention in the soil, reduction of the maximum temperature and decreased temperature fluctuations (ZANETTE et al., 2007; BIZARI et al., 2009; MARTORANO et al., 2009; SIMIDU et al., 2010; COELHO et al., 2013), which contribute to increasing the soil water storage capacity, favoring the increase of LA.

In both planting systems, there was a reduction of $A$ and $C i$ from the third day of suspension of irrigation and of $g s$ and $E$ from 5 days. The plants subjected to moderate stress showed recovery of these physiological variables 3 days after rewatering; between 13 and 17 days after rewatering, there was an increase in the values of these variables in relation to the control, especially in the no-tillage system (Figure 3) - a compensation effect. This same effect can be seen in the results of Anyia and Herzog (2004a, 2004b) for some cowpea varieties 7 days after resumption of irrigation. This increase in $A$ can be explained by the issuance of new leaves in plants in recovery (Figure $2 \mathrm{a}$ and $2 \mathrm{~b}$ ), which may have caused the increase in the photosynthetic activity of plants, as seen in cowpea by Leite and Virgens Filho (2004) and Mendes et al. (2007). 

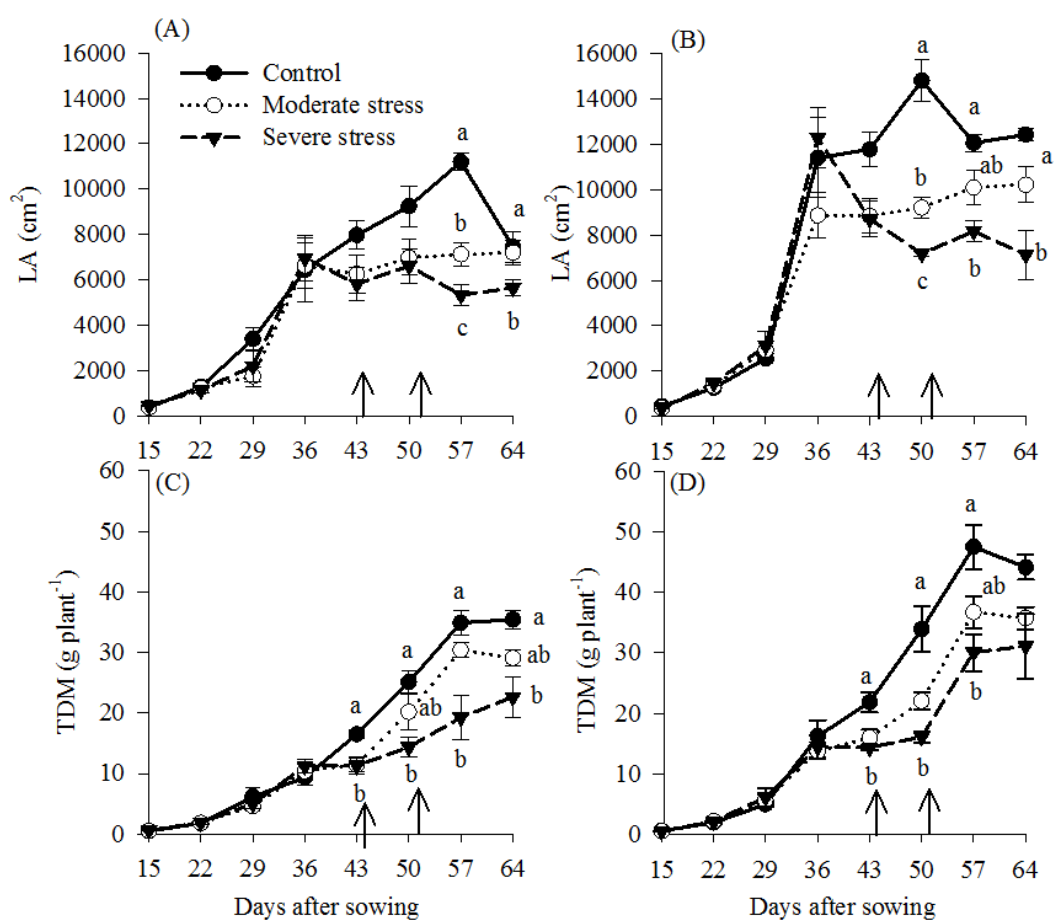

Figure 2. Leaf area (LA) and total dry matter (TDM) in cowpea plants grown for 64 days in conventional (A, C) and no-tillage (B, D) systems maintained under irrigated conditions (control) or subjected to moderate and severe stress and after rehydration (stress recovery). The arrow indicates the irrigation resumption time.
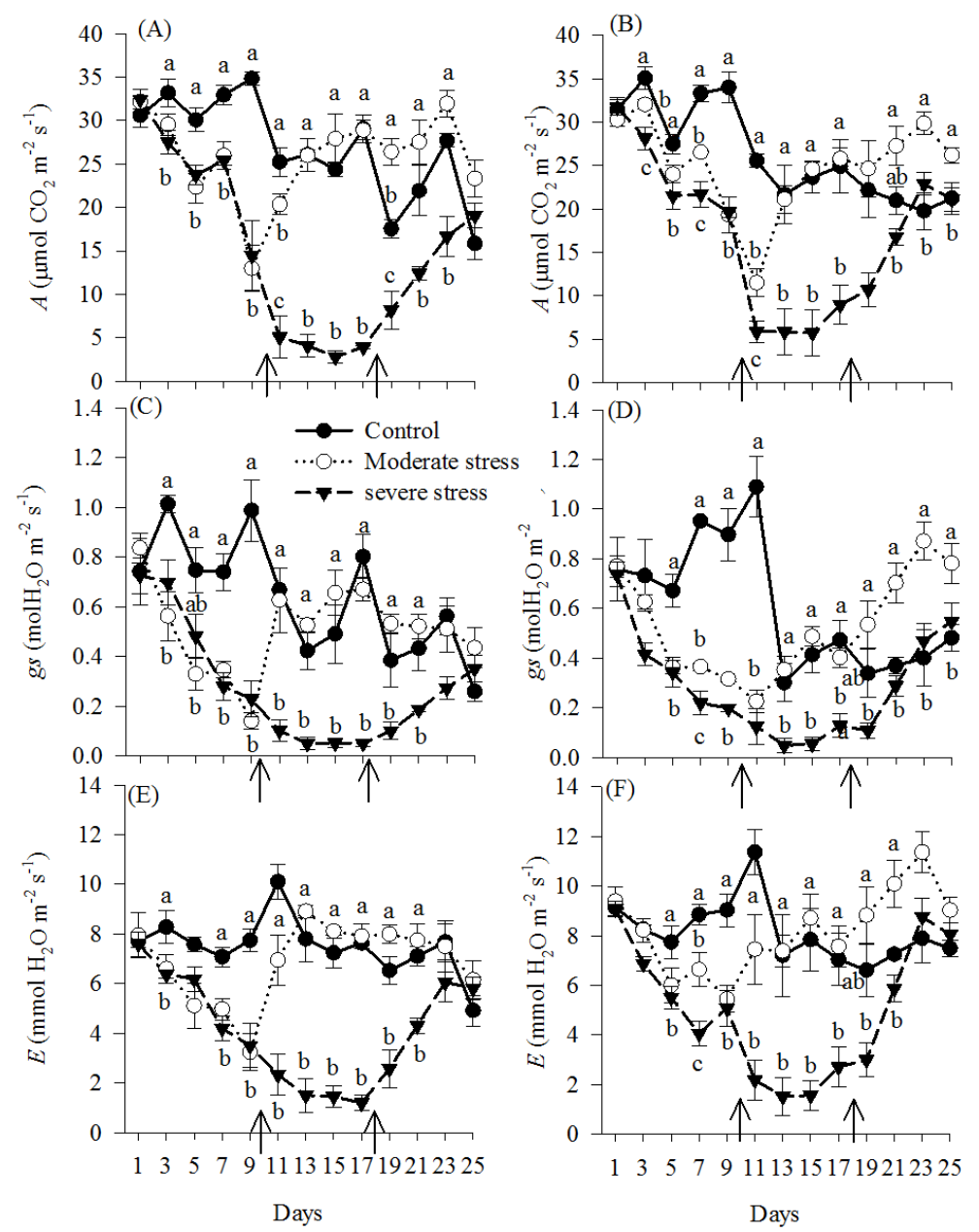

Figure 3. Net photosynthesis $(A)$, stomatal conductance $(g s)$ and transpiration $(E)$ of cowpea subjected to water stress and rehydration in conventional tillage $(\mathrm{A}, \mathrm{C}, \mathrm{E})$ and no-tillage $(\mathrm{B}, \mathrm{D}, \mathrm{F})$ systems. The arrow indicates the irrigation resumption time, 10 and 18 days, for moderate to severe water stress, respectively. 
Rewatering was performed 18 days after the suspension of irrigation in the severe stress treatment. Although there was recovery of all variables compared to the control, recovery was slower than in the intermediate stress, especially for the conventional tillage system, which only had recovery of all variables after 10 days of resumption of irrigation. Nevertheless, this is not considered to be indicative of damage to the photosynthetic apparatus; it only indicates that the recovery occurred from very low levels of these variables. The absence of damage to the photosynthetic apparatus also was observed in cowpea after drought/ rewatering by Souza et al. (2004).

Among the physiological variables, the most sensitive to the stress was gs. The control of stomatal opening in cowpea seems to be the immediate response to soil water reduction (POMPELLI et al., 2010; SILVA et al., 2010). Thus, plants under stress conditions tend to close their stomata to minimize water loss and maintain turgor, which comes to

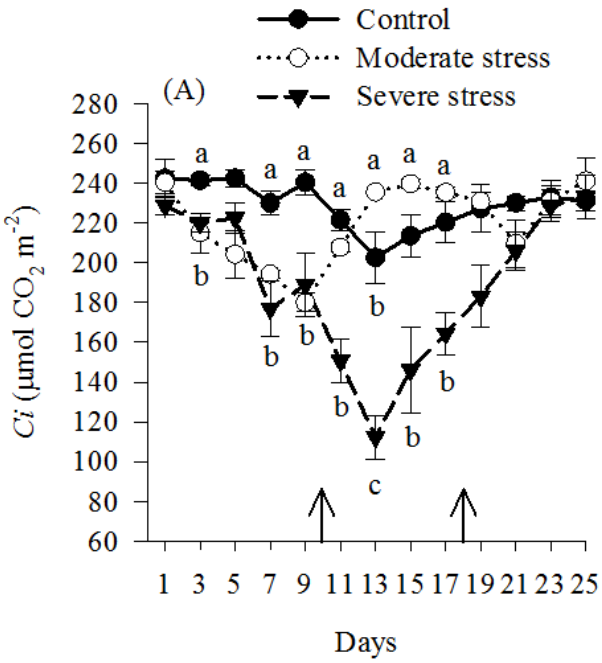

- Observed values $\mathrm{Y}=1.96+64.8 \mathrm{x}-34.94 \mathrm{x}^{2} \mathrm{R}^{2}=0.94 * *$

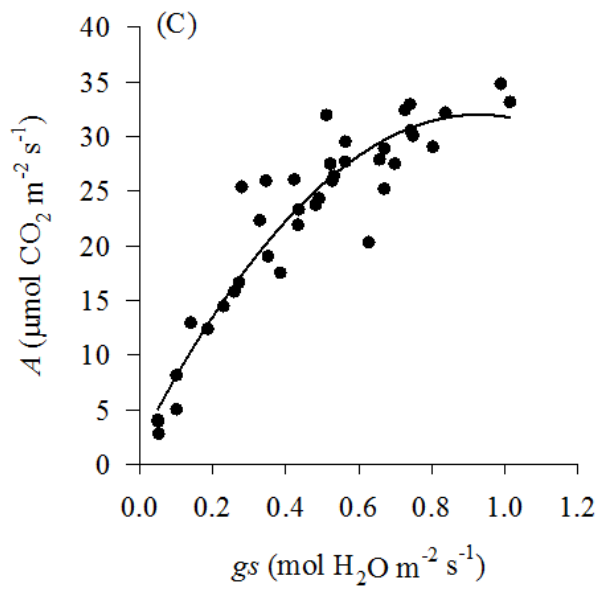

directly reflect the stoppage of plant biomass accumulation, especially in the stem, due to decreased $\mathrm{CO}_{2}$ intake (BRITO et al., 2013). This water conservation mechanism is an important strategy of defense, particularly in semi-arid regions, where there are long periods without rainfall associated with high temperatures, which makes cowpea one of the most widely grown crops in these regions.

The $A$ reduction was similar to that observed for $g s$. This relationship was linear for $g s$ values below $0.60 \mathrm{~mol} \mathrm{~m}^{-2} \mathrm{~s}^{-1}$ (Figure 4), indicating that $A$ was limited mainly by gs (MEDRANO et al., 2002) during the stress and initial phases of recovery (SOUZA et al., 2004). For $g s$ values exceeding 0.60 mol m $\mathrm{m}^{-2} \mathrm{~s}^{-1}, A$ was less related to $g s$, indicating that the latter was inhibited by factors other than soil water availability, such as light flux density; quality and duration of radiant energy; $\mathrm{CO}_{2}$ content in the air; and air temperature (LOPES; LIMA, 2015).

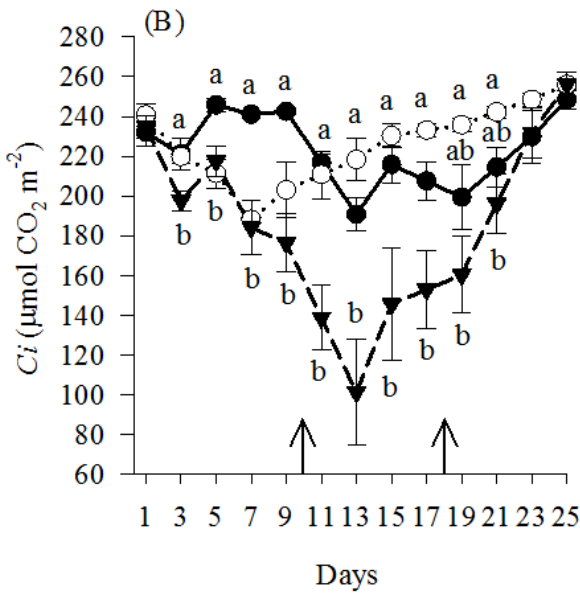

- Observed values

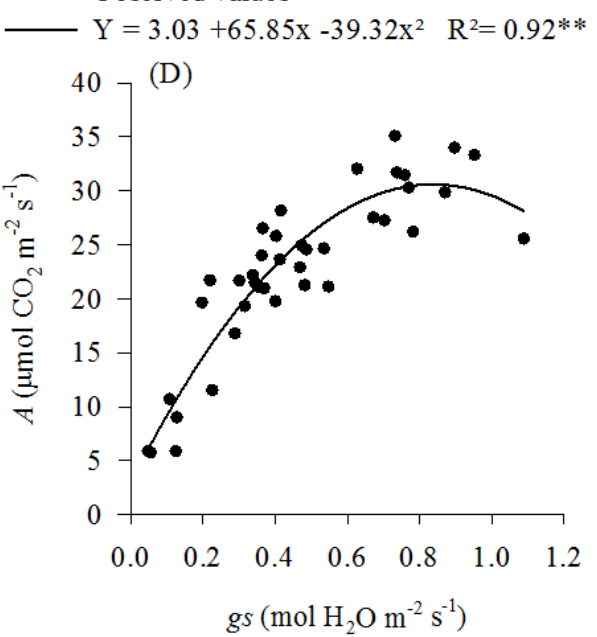

Figure 4. Internal $\mathrm{CO}_{2}$ concentration $(\mathrm{Ci})$ and the relationship between photosynthesis $(A)$ and stomatal conductance $(\mathrm{gs})$ of cowpea (Vigna unguiculata (L.) Walp.) subjected to water stress and rehydration. The arrow indicates the irrigation resumption time, 10 and 18 days, for moderate to severe water stress, respectively. 
According to Flexas et al. (2004), values less than $0.15 \mathrm{~mol} \mathrm{~m}^{-2} \mathrm{~s}^{-1}$ are severe stress indicators, which were observed for the two planting systems from the 11th day of stress. Similar values were observed by Oliveira, Fernandes and Rodrigues (2005), Mendes et al. (2007) and Nascimento et al. (2011) in the same crop.

There was no difference in $\Psi_{\mathrm{w}}$ among the different water conditions, evaluation periods and planting systems (Figure 5). The smallest $\Psi_{\mathrm{w}}$ was found at noon $(-1.6 \mathrm{MPa})$ and the largest observed at pre-dawn (-0.3 MPa). These values are close to those found by other authors for the same crop (PIMENTEL; HÉBERT, 1999; NASCIMENTO et al., 2011). The results indicate that cowpea is a crop that has a conservative drought-resistance mechanism, with high $\Psi_{\mathrm{w}}$ and efficient stomatal control.
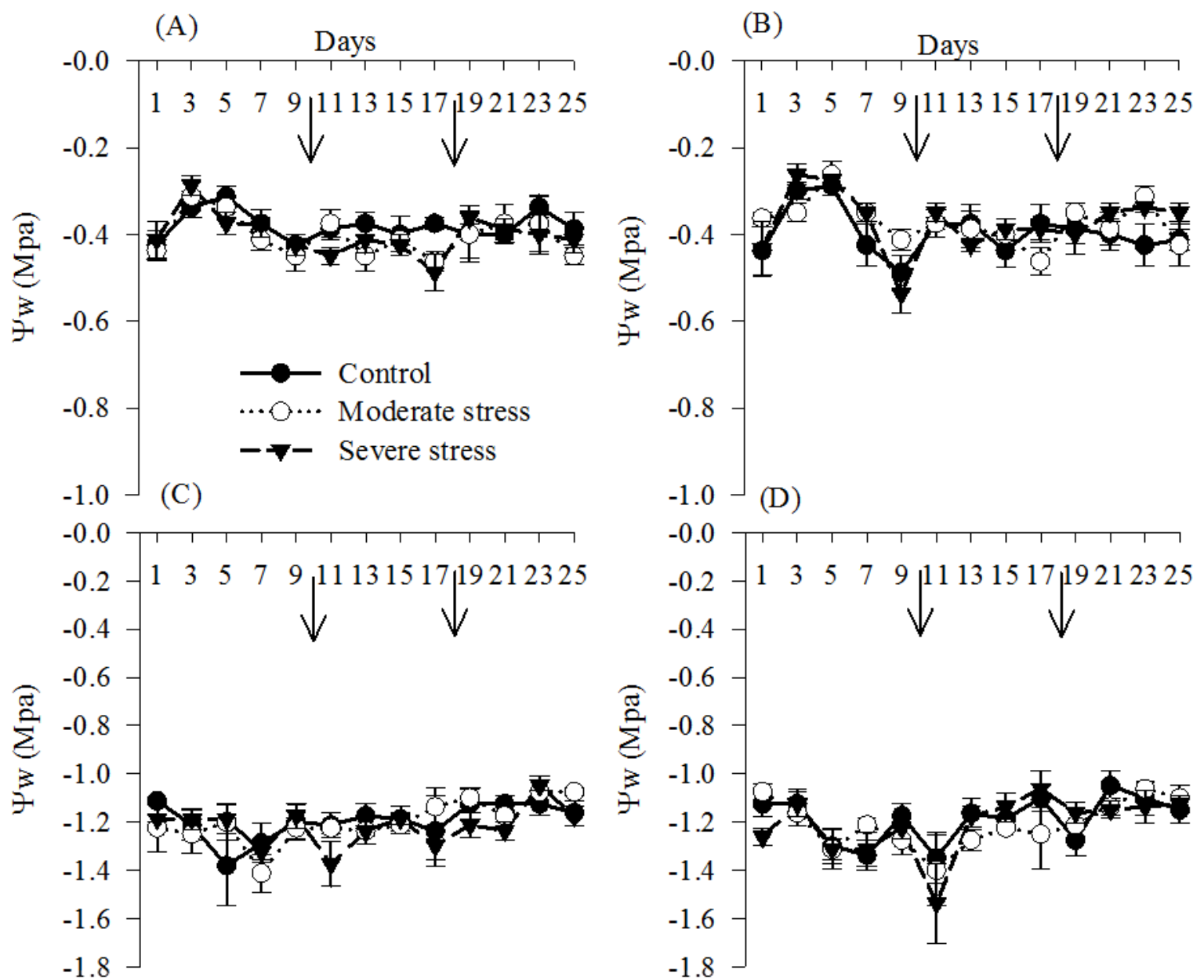

Figure 5. Leaf water potential $(\mathrm{Yw})$ at pre-dawn $(\mathrm{A}, \mathrm{B})$ and noon $(\mathrm{C}, \mathrm{D})$ of cowpea subjected to water stress and rehydration in conventional $(\mathrm{A}, \mathrm{C})$ and no-tillage $(\mathrm{B}, \mathrm{D})$ systems. The arrow indicates the irrigation resumption time, 10 and 18 days, for moderate to severe water stress, respectively.

\section{CONCLUSIONS}

Cowpea shows recovery of all physiological variables after moderate and severe water stress.

Stomatal closure is the main drought-resistance mechanism, and cowpea is a water-conservative species.

The planting systems do not affect photosynthesis.

The no-tillage system provides greater accumulation of biomass and leaf area.

\section{REFERENCES}

AKIBODE, S.; MAREDIA, M. Global and regional trends in production, trade and consumption of food legume crops. Michigan, 2011; p. 1-83.

ANYIA, A. O.; HERZOG, H. Genotypic variability in drought performance and recovery in cowpea under controlled environment. Journal Agronomy and Crop Science, Oxford, v. 190, n. 2, p. 151-159. 2004a.

ANYIA, A. O.; HERZOG, H. Water-use efficiency, leaf area and leaf gas exchange of cowpeas under mid-season drought. European Journal Agronomy, Montpellier, v. 20, n.4, p. 327-339. 2004b. 
BIZARI, D. R. et al. Consumo de água e produção de grãos do feijoeiro irrigado em sistemas plantio direto e convencional. Ciência Rural, Santa Maria, v. 39, n. 7, p. 2073-2079, 2009.

BRITO, M. E. B. et al. Crescimento, fisiologia e produção do milho doce sob estresse hídrico. Bioscience Journal, Uberlândia, v. 29, n. 5, p. 1244-1254, 2013.

COELHO, M. E. H. et al. Coberturas do solo sobre a amplitude térmica e a produtividade de pimentão. Planta Daninha, Viçosa, v. 31, n. 2, p. 369-378, 2013.

DAMATTA, F. M. Ecophysiology of tropical tree crops: an introduction. Brazilian Journal of Plant Physiology, Campos dos Goytacazes, v. 19, n. 4, p. 239-244, 2007.

FLEXAS, J. et al. Understanding down-regulation of photosynthesis under water stress: future prospects and searching for physiological tools for irrigation management. Annals of Applied Biology, Oxford, v. 144, n. 3, p. 273-283, 2004.

FONTES, P. C. R.; DIAS, E. N.; SILVA, D. J. H. Dinâmica do crescimento, distribuição de matéria seca na planta e produção de pimentão em ambiente protegido. Horticultura Brasileira, Vitória da Conquista, v. 23, n. 1, p. 94-99, 2005.

FREIRE FILHO, F. R. Feijão-caupi no Brasil: Produção, melhoramento genético, avanços e desafios. Teresina, PI: EMBRAPA meio Norte, 2011. $84 \mathrm{p}$.

FREITAS, R. M. O. et al. Crescimento de feijão-caupi sob efeito de veranico nos sistemas de plantio direto e convencional. Bioscience Journal, Uberlândia, v. 30, n. 2, p. 393-401, 2014.

FREITAS, R. M. O. et al. Produção de feijão-caupi sob efeito de veranico nos sistemas de plantio direto e convencional. Semina: Ciências Agrárias, Londrina, v. 34, n. 6, p. 3683-3690, 2013.

HALL, A. E. Phenotyping cowpeas for adaptation to drought. Frontiers in Physiology, Bethesda, v. 25, n. 3 , p. $155,2012$.

LEITE, M. L.; VIRGENS FILHO, J. S. Produção de matéria seca em plantas de caupi (Vigna unguiculata (L.) Walp) submetidas a déficits hídricos. Ciências Exatas e da Terra, Ciências Agrárias e Engenharias, Campina Grande, v. 10, n. 1, p. 43-51, 2004.

LOPES, N. F.; LIMA, M. G. S. Fisiologia da produção. 1. ed. Viçosa, MG: UFV, 2015. 492 p.
LOPES, W. A. R. et al. Análise do crescimento de tomate 'SM-16' cultivado sob diferentes coberturas de solo. Horticultura Brasileira, Vitória da Conquista, v. 29, n. 4, p. 554-561, 2011.

MAROUELLI, W. et al. Uso da água e produção do tomateiro para processamento em sistema de plantio direto com palhada. Pesquisa Agropecuária Brasileira, Brasília, v. 41, n. 9, p. 1399-1404, 2006.

MARTORANO, L. G. et al. Indicadores da condição hídrica do solo com soja em plantio direto e preparo convencional. Revista Brasileira de Engenharia Agrícola e Ambiental, Campina Grande, v. 13, n. 4, p. 397-405, 2009.

MEDRANO, H. et al. Regulation of photosynthesis of $\mathrm{C} 3$ plants in response to progressive drought: stomatal conductance as a reference parameter. Annals of Botany, Exete, v. 89, n. 7, p. 895-905, 2002.

MENDES, R. M. S. et al. Relações fonte-dreno em feijão-de-corda submetido à deficiência hídrica. Ciência Agronômica, Fortaleza, v. 38, n. 1, p. 95-103, 2007.

NASCIMENTO, S. P. et al. Tolerância ao déficit hídrico em genótipos de feijão-caupi. Revista Brasileira de Engenharia Agrícola e Ambiental, Campina Grande, v. 15, n. 8, p. 853-860, 2011.

OBALUM, S. E.; OBI, M. E. Physical properties of a sandy loam Ultisol as affected by tillage-mulch management practices and cropping systems. Soil \& Tillage Research, Amsterdam, v. 108, n. 1-2, p. 30-36, 2010.

OLIVEIRA, A. D.; FERNANDES, E. J.; RODRIGUES, T. J. D. Condutância estomática como indicador de estresse hídrico em Feijão. Engenharia Agrícola, Jaboticabal, v. 25, n. 1, p. 86-95, 2005.

PIMENTEL, C.; HÉBERT, G. Potencial fotossintético e condutância estomática em espécies de feijão caupi sob deficiência hídrica. Revista Brasileira de Fisiologia Vegetal, Campinas, v. 11, n. 1, p. 7-11, 1999.

POMPELLI, M. F. et al. Photosynthesis, photoprotection and antioxidant activity or purging nut under drought deficit and recovery. Biomass and Bioenergy, Oxford, v. 34, n. 8, p. 1207-1215, 2010.

SALEHI-LISAR, S. Y.; BAKHSHAYESHAN-AGDAM, H. Drought Stress in Plants: Causes, Consequences, and Tolerance. In.: HOSSAIN, M. A. et al. (Eds.). Drought Stress Tolerance in Plants: Physiology and Biochemistry. 
New York: Springer International Publishing, 2016. v. 1, cap.1, p. 1-16.

SANTOS, H. G. et al. Sistema brasileiro de classificação de solo. 2. ed. Brasília, DF: EMBRAPA Solos, 2006. 306 p.

SANTOS, R. F.; CARLESSO, R. Déficit hídrico e os processos morfológico e fisiológico das plantas. Revista Brasileira de Engenharia Agrícola e Ambiental, Campina Grande, v. 2, n. 3, p. 287-294, 1998.

SILVA, E. N. et al. Photosynthetic changes and protective mechanisms against oxidative damage subjected to isolated and combined drought and heat stresses in Jatropha curcas plants. Journal of Plant Physiology, Jena, v. 167, n. 14, p. 1157-1164, 2010.

SILVA, F. A. S. E.; AZEVEDO, C. A. V. Versão do programa computacional Assistat para o sistema operacional Windows. Revista Brasileira de Produtos Agroindustriais, Campina Grande, v. 4, n. 1, p. 71-78, 2002.

SILVA, P. I. B. et al. Crescimento de pimentão em diferentes arranjos espaciais. Pesquisa agropecuária brasileira, Brasília, v. 45, n. 2, p. 132-139, 2010.

SIMIDU, H. M. et al. Efeito do adubo verde e época de semeadura sobre a produtividade do feijão, em plantio direto em região de cerrado. Acta Scientiarum Agronomy, Maringá, v. 32, n. 2, p. 309-315, 2010.

SOUZA, R. P. et al. Photosynthetic gas exchange, chlorophyll fluorescence and some associated metabolic changes in cowpea (Vigna unguiculata) during water stress and recovery. Environmental and Experimental Botany, Oxford, v. 51, n. 60, p. 45-56, 2004.

SOUZA, M. S. et al. Comparação de métodos de mensuração de área foliar para a cultura da melancia. Pesquisa Agropecuária Tropical, Goiânia, v. 42, n. 2, p. 241-245, 2012.

ZANETTE, S. V. et al. Análise espacial da umidade do solo cultivado com soja sob dois sistemas de manejo. Revista Brasileira de Engenharia Agrícola e Ambiental, Campina Grande, v. 11, n. 3, p. 239-247, 2007. 